\title{
Seasonal variation and speciation of dissolved iron in an artificial surface water body
}

\author{
Semaghiul BIRGHILA, Georgiana BARONESCU, Anca DUMBRAVA* \\ Ovidius University of Constanta, Department of Chemistry and Chemical Engineering, 124 Mamaia Blvd., \\ Constanta 900527, Romania
}

\begin{abstract}
The aquatic chemistry of iron is an important issue since iron is a micronutrient for the growth of phytoplankton. Its concentration in surface waters involves many environmental aspects, from the quality of a particular water to the control of atmospheric carbon dioxide. Dissolved iron can exist in water as ferrous and ferric iron, and the equilibrium between these two forms, as well as the precipitation and solubilization of iron, depends on many natural and anthropic factors. We studied the variation for an year of $\mathrm{Fe}$ (II) and total iron concentration into Poarta Alba - Midia Navodari Canal, an artificial surface water which connects Danube River with Black Sea. The results indicate a high iron concentration in surface water and a seasonal variation of iron concentration and speciation, which can be correlated with the oxidable matter content.
\end{abstract}

Keywords: iron speciation, ferrous-ferric equilibrium, surface water, chemical oxygen demand, Danube - Black Sea Canal.

\section{Introduction}

Iron is an important metal for life, mineral world, and industry, playing a very significant role in material civilization progress [1]. Iron is widely distributed in nature and its efficacy in environmental and biological systems depends on physical and chemical properties. For aquatic systems, it is the most studied trace element in surface waters [2]. The iron chemistry, with its various aspects, continues to be an interesting domain for researchers. Some important issues involving the relevance of iron in nature, like iron sources, iron speciation, iron cycle, iron uptake by phytoplankton and aquatic plants in freshwater, as well as the environmental impact, are associated with iron biogeochemistry. The iron complexes in aquatic systems represent an interesting application of coordination chemistry in environmental sciences. The renewed interest in aquatic iron chemistry in last 30 years [3] is due to the assumption that it controls the ocean productivity, having as consequence the sequestration of carbon into the ocean water and the influence in atmospheric carbon dioxide concentration [4]. Although iron is the second most abundant metal on the Earth and the fourth most abundant element in the Earth's crust, its concentration is rather low in natural water bodies mainly because of its low solubility in oxygenated waters. The bioavailability of dissolved iron in surface waters is an important problem which really influences its implication in carbon sequestration [5]. It remains a challenge for researchers to explain the linkages between iron chemistry and biological processes which are involved in iron availability in surface waters $[4,6,7]$.

In aquatic systems (i.e. surface waters and their sediments), iron occurs as neutral atoms (metallic iron, iron metal), or as ions (i.e. Fe(II) or ferrous iron, and $\mathrm{Fe}(\mathrm{III})$ or ferric iron). In ionized form, iron can exist as complexes in solution, but also in sediments, which are synthesized with inorganic and organic molecules/ions as ligands, including water. The availability of iron in ocean waters, predominately limited by the solubility of $\mathrm{Fe}(\mathrm{III})$, depends essentially on the presence of iron-binding organic chelators. The particulate iron is dissolved by bacteria, which also release ligands for iron ions complexation and keep them into solution. The oxidation state of iron in an aquatic system and its redox processes are determined by the dissolved oxygen concentration. Redox reactions, complexation with inorganic and organic ligands, adsorption and precipitation are involved in the chemistry of iron in natural waters $[4,6,8,9]$. The sediments are also involved in redox transformation of iron in natural waters. It is known that most aquatic systems are anoxic (without oxygen) as a result of the bacterial oxidation of particulate organic matter (dead and decomposing aquatic plants, algae and other organisms, anthropogenic oxygen-demanding materials, etc.) and in a such anoxic environment iron exists in the reduced form as $\mathrm{Fe}(\mathrm{II})$, often associated with sulfide (black FeS, insoluble). In the oxic (oxygen-containing) water, iron is in the oxidized form, which exists as particulate or colloidal ferric

\footnotetext{
* Corresponding author. E-mail address: adumbrava@univ-ovidius.ro (Anca Dumbrava)
} 
hydroxide (hydrous oxide). In this form, iron is a scavenger of many chemicals, such as heavy metals, organic molecules, phosphorus compounds, etc., which become generally unavailable or get a low toxicity for organisms. In time, $\mathrm{Fe}(\mathrm{III})$ hydroxide is deposited in sediments and falling particles scavenge the iron from solution. In sediment anoxic conditions, iron is reduced from $\mathrm{Fe}$ (III) to $\mathrm{Fe}(\mathrm{II})$. Because almost always sulfide ions are also present in sediments, $\mathrm{Fe}(\mathrm{II})$ can precipitate as $\mathrm{FeS}$. In aquatic systems the anoxic sediments and oxic water are often mixed (by organisms activity, watercrafts, winds, currents, etc.), so $\mathrm{Fe}(\mathrm{II})$ comes in oxic areas, being oxidized, and $\mathrm{Fe}(\mathrm{III})$ comes in anoxic areas, being reduced. In undisturbed aquatic systems, the sediments surface has a reddish-brown color, characteristic for $\mathrm{Fe}(\mathrm{III})$ as hydroxide, which covers black ferrous sulfide/polysulfide in anoxic environment $[4,6,8,10$ 12].

A lower concentration of $\mathrm{CO}_{2}$ in atmosphere can be maintained by the photosynthesis of organic matter in the surface ocean, which is considered a "biological pump" for carbon. The efficiency of this pump can be limited by sunlight and the bioavailability of macronutrients, like nitrate and phosphate. Iron is a micronutrient for the growth of phytoplankton. The iron concentration in a column of ocean water increases from surface to depth because of iron biological uptake in surface waters and release from the degrading organic material at depth [13]. Some global changes as rapid urbanization and growth of industries, and also a rapid growth of population, result in significant changes in speciation, concentration and bioavailability of iron in lake water and sediment, which influence the structure and function of lake ecosystems [6].

We determined the concentration of iron, as Fe(II) and total iron, and studied its seasonal variation in Poarta Alba - Midia Navodari Canal (PAMNC) surface water, a $32.7 \mathrm{~km}$ long branch of Danube Black Sea Canal (DBSC), situated in Romania, Constanta County. The canal water is taken from the Danube, upstream of Cernavoda town, and discharged into the Black Sea at Agigea. The PAMNC is linking Poarta Alba village with Navodari town, flowing into Black Sea. The main uses for DBCS waters are navigation, flood protection and urbanization. According to the quality standards, exceeding of limits for some indicators (dissolved oxygen, ammonia nitrate, chemical oxygen consumption (COD-Mn), and chlorides) was reported over the time. The water eutrophication and the development of macrophyte algae were identified for DBSC, in warm seasons. The discharge of wastewaters from riverine settlements affects PAMNC water quality, which is very important for the chemical and ecological status of Black Sea coastal waters [14].

\section{Materials and methods}

\subsection{Materials}

The high purity reagents were obtained from SigmaAldrich (iron standard solution; 1, 10-phenanthroline monohydrate, $\mathrm{C}_{12} \mathrm{H}_{8} \mathrm{~N}_{2} \cdot \mathrm{H}_{2} \mathrm{O}$; ethanol, $\mathrm{C}_{2} \mathrm{H}_{5} \mathrm{OH}$; hydroxylamine hydrochloride, $\mathrm{NH}_{2} \mathrm{OH} \cdot \mathrm{HCl}$; oxalic acid, $\mathrm{HO}_{2} \mathrm{CCO}_{2} \mathrm{H}$; sodium acetate, $\mathrm{CH}_{3} \mathrm{COONa}$; potassium permanganate, $\mathrm{KMnO}_{4}$ ) and Merck (sulfuric acid 95-97\%, $\mathrm{H}_{2} \mathrm{SO}_{4}$ ), being used as received without further purification.

\subsection{Sampling}

Water samples were collected during 2016 - 2017 period, namely in autumn 2016 (October and November), winter 2017 (February), spring 2017 (March, April, May) and summer 2017 (June, July) from Poarta Alba - Midia Navodari Canal. The samples were stored in Teflon bottles, filtered to remove particulate material and kept refrigerated at $4^{\circ} \mathrm{C}$, away from light, prior to analysis.

\section{3. $\mathrm{pH}$ and conductivity measurement}

The $\mathrm{pH}$ and conductivity were measured with a $300 \mathrm{i}$ conductivity meter (Cond 300i) from WTW Company.

\subsection{Iron determination}

The measurements were performed using the molecular absorption spectrometry in visible domain, with a DR 3900 spectrophotometer from Hach Company. The concentration of $\mathrm{Fe}(\mathrm{II})$ was determined by a colorimetric method, using 1, 10phenantroline as color reagent $[15,16]$. The total dissolved iron content was determined as Fe(II), after the reduction of $\mathrm{Fe}(\mathrm{III})$ with hydroxylamine. The method of the standard addition, which is applied for determination of low concentration of metals in samples with variable chemical matrix, was used in order to increase the sensitivity of the analytical determination [17-19]. The effect of $\mathrm{pH}$, temperature, complexation time and reagent amounts were previously studied [20-22] and the determinations were done in optimal conditions.

\subsection{Chemical oxygen demand}

The content of organic matter susceptible to oxidation was estimated by chemical oxygen demand (COD), using potassium permanganate as strong chemical oxidant (COD-Mn) [23].

All determinations were made in triplicate and reported results represent mean value \pm standard deviation (sd).

\section{Results and discussion}

The sampling point was situated on the left side of PAMNC, near Navodari town, at $44^{\circ} 18^{\prime} 53.0^{\prime \prime} \mathrm{N}$ and 283'04.1'E (Fig. 1). 


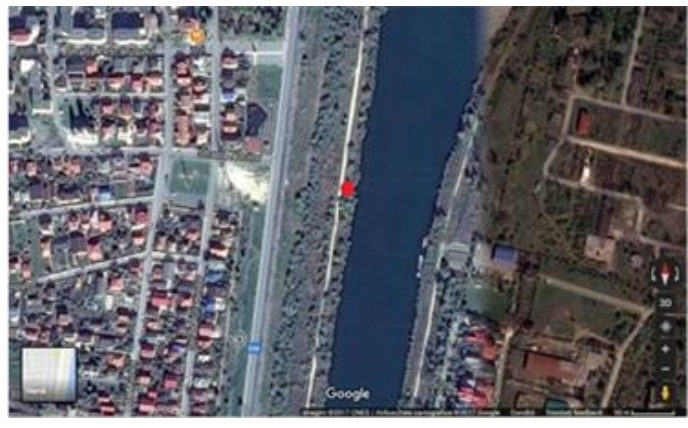

Figure 1. Localization of studied area on PAMNC left side.

A preliminary characterization of water samples involved the determination of $\mathrm{pH}$ and conductivity. The value of $\mathrm{pH}$ is an important factor for chemical transformation of iron in surface waters, as Pourbaix diagram describes $[24,25]$. The conductivity of water is a measure of the quantity of dissolved ions, also influencing the solubility and reactivity of iron.

The parameters like $\mathrm{pH}$ and conductivity (Table 1) had irregular variation, with rather small differences. The lowest value for conductivity can be correlated with lowest water temperature in winter (February), meaning a lower solubility of ionizable compounds, thus a low concentration of dissolved ions. A low value of $\mathrm{pH}$ was determined in autumnwinter and the increase in spring can be due to the biological activity. The high $\mathrm{pH}$ value registered in May remained comparable and even higher for both samples collected in summer.

Table 1. The conductivity, $\mathrm{pH}$ and temperature of surface water samples (mean \pm sd).

\begin{tabular}{|l|c|c|c|}
\hline \multicolumn{1}{|c|}{ Month } & $\begin{array}{c}\text { Conductivity } \\
(\mathbf{m S / c m})\end{array}$ & $\mathbf{p H}$ & $\begin{array}{c}\text { Temperature } \\
\left({ }^{\circ} \mathbf{C}\right)\end{array}$ \\
\hline $\begin{array}{l}\text { October } \\
2016(\mathbf{1})\end{array}$ & $3.14 \pm 0.29$ & $7.84 \pm 0.21$ & 14 \\
\hline $\begin{array}{l}\text { November } \\
2016(\mathbf{2})\end{array}$ & $3.16 \pm 0.19$ & $6.63 \pm 0.36$ & 12 \\
\hline $\begin{array}{l}\text { February } \\
2017(\mathbf{3})\end{array}$ & $2.89 \pm 0.45$ & $7.85 \pm 0.31$ & 1 \\
\hline $\begin{array}{l}\text { March } \\
2017(\mathbf{4})\end{array}$ & $3.70 \pm 0.31$ & $7.70 \pm 0.43$ & 7 \\
\hline $\begin{array}{l}\text { April 2017 } \\
(\mathbf{5})\end{array}$ & $3.85 \pm 0.39$ & $8.45 \pm 0.69$ & 17 \\
\hline $\begin{array}{l}\text { May 2017 } \\
(\mathbf{6})\end{array}$ & $3.42 \pm 0.34$ & $9.0 \pm 0.78$ & 21 \\
\hline $\begin{array}{l}\text { June 2017 } \\
(\mathbf{7})\end{array}$ & $3.63 \pm 0.58$ & $8.81 \pm 0.42$ & 29 \\
\hline $\begin{array}{l}\text { July 2017 } \\
(\mathbf{8})\end{array}$ & $3.68 \pm 0.17$ & $9.63 \pm 0.30$ & 29 \\
\hline
\end{tabular}

The variation of iron concentration (ferrous, ferric, and total iron) is presented in Fig. 2. The concentration of ferrous and total iron was determined, while the concentration of ferric iron was calculated as difference between total and ferrous iron concentrations.

In natural conditions, the main sources of iron in surface waters are the eroded rocks and surrounding soil, being controlled by factors as geological process, soil composition, environmental temperature, precipitation and hydrology [6]. The iron is also deposited from air, and it is considered that in the remote surface waters of the open ocean the main source of iron is atmospheric dust deposition $[6,26]$. In last decades, due to the anthropic activity, new sources of iron were evidenced [4].

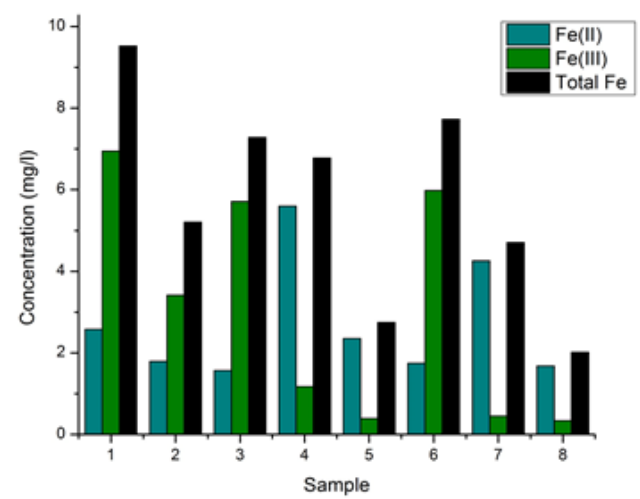

Figure 2. The seasonal variation of iron concentration in water samples.

In brief, iron, together with some other nutrient elements (nitrogen, phosphorus, and sulfur), falls into surface waters from natural (as dust, rain water, dead vegetable matter, etc.) or anthropic sources (as wastewater discharges), so the total iron concentration is influenced both by natural and anthropic factors. The chemical composition of the surface waters, together with iron inputs and removal processes, and also internal iron recycling control the iron speciation [6].

Because some natural and anthropic sources of iron consist in elemental iron, the solubilization of metal is also important. This process depends on chemical composition of surface water, being influenced mostly by the $\mathrm{pH}$ and dissolved ligands.

The determined concentration of total iron is in the $2-10 \mathrm{mg} / \mathrm{l}$ range, for all water samples, with a seasonal variation. On the basis of total iron concentration (over $2 \mathrm{mg} / \mathrm{l}$ ), PAMNC water can be include in the fifth quality class, having in view the Romanian legislation [27].

The variation of iron concentration is irregular, rather unpredictable. The lowest values of total iron concentration were determined in April (5) and July (8), being correlated with rainy weather, respective with biological and anthropic activity. Generally, in spring and summer the biologic activity, which involves the metal uptake and also $\mathrm{pH}$ rising, can explain the decrease of total iron concentration.

For discussion and understanding the equilibrium between ferrous and ferric iron in studied surface water, we determined the chemical oxygen demand (Table 2), which is defined as "a measure of the oxygen equivalent of the organic matter content of a sample that is susceptible to oxidation by a strong chemical oxidant" [28]. 
Table 2. COD-Mn values for surface water samples (mean \pm sd).

\begin{tabular}{|l|c|}
\hline \multicolumn{1}{|c|}{ Month } & \multicolumn{1}{c|}{$\begin{array}{c}\text { COD-Mn } \\
\left(\mathrm{mg} \mathrm{O}_{2} / \mathrm{l}\right)\end{array}$} \\
\hline October 2016 (1) & $5.276 \pm 0.13$ \\
\hline November 2016 (2) & $8.153 \pm 0.07$ \\
\hline February 2017 (3) & $4.156 \pm 0.17$ \\
\hline March 2017 (4) & $6.230 \pm 0.21$ \\
\hline April 2017 (5) & $15.341 \pm 0.67$ \\
\hline May 2017 (6) & $5.130 \pm 0.30$ \\
\hline June 2017 (7) & $10.231 \pm 0.47$ \\
\hline July 2017 (8) & $8.313 \pm 0.58$ \\
\hline
\end{tabular}

An interesting correlation between ferrous/total iron ratio and COD-Mn is shown in Fig. 3. Thus, a similar trend for the variation of $\mathrm{Fe}$ (II)/total $\mathrm{Fe}$ ratio and COD-Mn can be noted. A high value for CODMn can be correlated with a high amount of oxidable matter in water. In presence of oxidable matter, iron can act as an oxidizing agent, so it is reduced to Fe(II) which is expected to be the predominant form of iron in water. The organic compounds, resulted by the decomposition of dead vegetable matter or from anthropic sources, can act also as iron-binding dissolved organic ligands, solubilizing the iron [5] and, as result, a higher concentration of iron can be found in water.

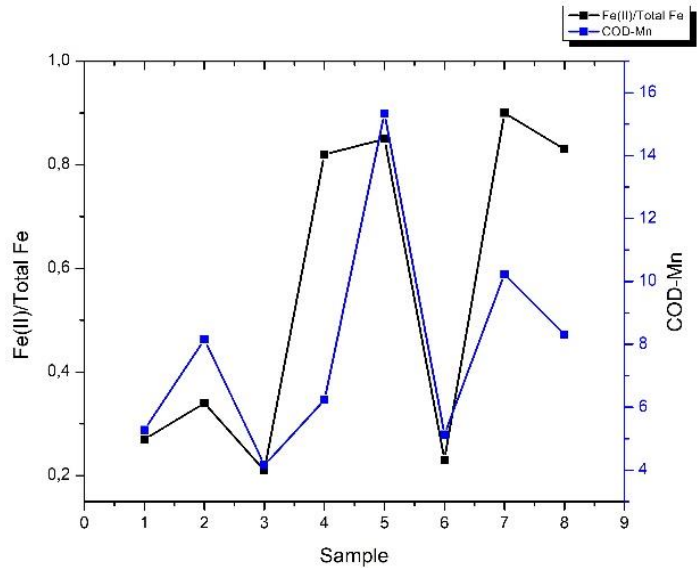

Figure 3. A correlation between the ratio of ferrous and total iron concentrations (mg/l), and COD-Mn

$\left(\mathrm{mg} \mathrm{O}_{2} / \mathrm{l}\right)$ for analyzed surface water samples.

The spontaneous chemical oxidation of ferrous to ferric iron is a complex process, which involves a variety of partially oxidized metastable ferrous-ferric intermediates, depending on the environmental conditions like $\mathrm{pH}$, temperature, solution composition and oxidation rate [29]. In autumn, the dead vegetable matter decayed and a reductive medium is generated in the surface waters, together with iron ions and organic compounds, which are released in water through rather slow processes. Before release of ligands and solubilization of iron by complexation, a removal of iron form water, most probably by precipitation, resulted in a decrease of total iron concentration. The ferric iron forms highly insoluble oxides and hydroxides at neutral $\mathrm{pH}$ and ferrous iron, which exist usually as dissolved ions, can form insoluble salts, if water contains high level of carbonate, sulfide and orthophosphate ions [6]. Therefore, in November (2) a lower concentration of total iron, and also of $\mathrm{Fe}(\mathrm{II})$, compared with October (1), was determined.

The concentration of total iron is comparable to that determined for Danube River and the decrease from winter to spring and summer is also similar [18].

In winter, the decrease of temperature increased the oxygen solubility, so iron is mostly oxidized to ferric iron, therefore the concentration of ferrous iron decreased. The lowest percent of $\mathrm{Fe}(\mathrm{II})$ in total $\mathrm{Fe}$ $(21 \%)$ was determined in February (3) (Fig. 2), when the water temperature was lowest, after a long period of low temperatures. A high temperature in June (7) and July (8) means a low oxygen solubility, so a high concentration of reduced iron. Indeed, the highest percent of $\mathrm{Fe}$ (II) (90\%) was determined in June (7) (Fig. 2). A possible decrease of oxidable organic matter in July (8), compared to June (7), can explain a small decrease of ferrous iron percent $(83 \%)$ in water (8), both samples being collected at same temperature. The iron-reducing and iron-oxidizing bacteria are also involved in the reversible ferrous ferric transformation [30].

\section{Conclusions}

We determined the concentration of ferrous and total iron by molecular absorption spectroscopy, using standard addition method, in an artificial surface water body, namely PAMNC, over a year (autumn 2016 - summer 2017). The results indicated a poor chemical quality, in all seasons. The concentration of iron and the ratio between ferrous and total iron concentrations can be correlated with season (temperature of water, biological uptake, degradation of organic matter). The COD-Mn has a similar variation as $\mathrm{Fe}(\mathrm{II}) /$ total $\mathrm{Fe}$ ratio, a high value for $\mathrm{COD}$ involving the reduction of $\mathrm{Fe}$ (III) to $\mathrm{Fe}(\mathrm{II})$ by oxidable compounds.

Conflicts of interest: The authors declare no conflict of interest. 


\section{References}

[1]. N. N. Greenwood, A. Earnshaw, Chemistry of the Elements, second edition, Greenwood Butterworth-Heinemann, 1997.

[2]. X. Pu, B. Hu, Z. Jiang, C. Huang, Speciation of dissolved iron(II) and iron(III) in environmental water samples by gallic acid-modified nanometer-sized alumina micro-column separation and ICP-MS determination, Analyst 130 (2005) 1175-1181. DOI: 10.1039/b502548f

[3]. X. Zhu, R. Zhang, S. Liu, Y. Wu, Z. Jiang, J. Zhang, Seasonal distribution of dissolved iron in the surface water of Sanggou Bay, a typical aquaculture area in China, Marine Chemistry 189 (2017) 1-9.

DOI: 10.1016/j.marchem.2016.12.004

[4]. P.W. Boyd, M. J. Ellwood, The biogeochemical cycle of iron in the ocean, Nature Geoscience 3 (2010) 675-682. DOI: 10.1038/ngeo964

[5]. A.M. Aguilar-Islas, M.J.M. Séguret, R. Rember, K.N. Buck, P. Proctor, C.W. Mordy, N.B. Kachel, Temporal variability of reactive iron over the Gulf of Alaska shelf, Deep-Sea Research II 132 (2016) 90-106. Doi: 10.1016/j.dsr2.2015.05.004

[6]. W. Xing, G. Liu, Iron biogeochemistry and its environmental impacts in freshwater lakes, Fresenius Environmental Bulletin 20 (2011) $1339-1345$.

[7]. G. Zhuang, Z. Yi, G.T.Wallace, Iron(II) in rainwater, snow, and surface seawater from a coastal environment, Marine Chemistry 50 (1995) 41-50. DOI: 10.1016/03044203(95)00025-M

[8]. A. Jones-Lee, G. F. Lee, Role of iron chemistry in controlling the release of pollutants from resuspended sediments, Journal of Remediation 16 (2005) 33-41.

[9]. F.J. Millero, W. Yao, J. Aicher, The speciation of $\mathrm{Fe}(\mathrm{II})$ and $\mathrm{Fe}(\mathrm{III})$ in natural waters, Marine Chemistry 50 (1995) 21-39. DOI: 10.1016/0304-4203(95)00024-L

[10]. X. Liu, F.J. Millero, The solubility of iron in seawater, Marine Chemistry 77 (2002) 43- 54.

[11]. J.D. Hem, W.H. Cropper, Survey of ferrousferric chemical equilibria and redox potentials, in "Chemistry of iron in natural water", Washington, U.S. Govt. Print. Off., 1962.

[12]. W. Stumm, G.F. Lee, Oxygenation of ferrous iron, Industrial and Engineering Chemistry 53 (1961) 143-146.

[13]. D. E. Archer, A model of the iron cycle in the ocean, Global Biogeochemical Cycles 14 (2000) 269-279.

[14]. U. Schmedtje (overall coordinator and editor), The Danube river basin district, prepared by International Commission for the Protection of the Danube River (ICPDR) in cooperation with the countries of the Danube River Basin District, International Commission for the Protection of the Danube River Vienna International Centre, Vienna 2005.

[15]. D.J. Pietrzyh, C.W. Frank, Analytical Chemistry, Academic Press, New York, 1979.

[16]. J.O. Hibbits, W.F. Davis, M.R. Menke, The determination of iron with 1, 10-phenanthroline, Talanta 8 (1961) 163-165. DOI:10.1016/00399140(61)80050-7

[17]. S. Dobrinas, S. Birghila, A. Dumbrava, Determination of $\mathrm{Fe}, \mathrm{Cu}, \mathrm{Cr}$ from surface waters by standard addition method, Ovidius University Annals of Chemistry 16 (2005) 51 53.

[18]. A. Dumbrava, S. Birghila, Analysis of some metal levels in Danube river water, Environmental Engineering and Management Journal 8 (2009) 219-224.

[19]. I. Enache, S. Birghila, A. Dumbrava, The Danube River water quality characteristics in the Braila Town, Ovidius University Annals of Chemistry 20 (2009) 146-152.

[20]. S. Birghila, A. Dumbrava, S. Dobrinas, Determination of heavy metals from ecosystem of Vrancea Mountains, Environmental Engineering and Management Journal 3 (2004) $695-700$.

[21]. A. Dumbrava, S. Dobrinas, S. Birghila, Water quality characteristics along the course of the Danube River. I. The Rasova area, Ovidius University Annals of Chemistry 18 (2007) 85 90.

[22]. A. Dumbrava, S. Dobrinas, S. Birghila, Water quality characteristics along the course of the Danube River. II. The Harsova area, Ovidius University Annals of Chemistry 18 (2007) 124 $-131$.

[23]. STAS 3002-85 - Drinking water. Determination of oxidable organic substances (in Romanian).

[24]. P. Atkins, T. Overton, J. Rourke, M. Weller, F. Armstrong, Shriver and Atkins' Inorganic Chemistry, fifth edition, Oxford University Press, 2010.

[25]. H.H. Huang, The Eh-pH diagram and its advances, Metals 6 (2016) 23. DOI: 10.3390/met6010023

[26]. P.J. Worsfold, M.C. Lohan, S.J. Ussher, A.R. Bowie, Determination of dissolved iron in seawater: A historical review, Marine Chemistry 166 (2014) 25-35.

DOI: $10.1016 /$ j.marchem.2014.08.009

[27]. Minister Order 161/2006 for the approval of the "Normative on the classification of surface 
water quality in order to establish the ecological status of the water bodies" (in Romanian).

[28]. American Public Health Association, Standard Methods for the Examination of Water and Wastewater, $19^{\text {th }}$ ed., 1995.

[29]. B. Morgan, O. Lahav The effect of $\mathrm{pH}$ on the kinetics of spontaneous $\mathrm{Fe}(\mathrm{II})$ oxidation by $\mathrm{O}_{2}$ in aqueous solution - basic principles and a simple heuristic description, Chemosphere 68 (2007) 2080-2084.

DOI:10.1016/j.chemosphere.2007.02.015
[30]. K.G. Taylor, K.O. Konhauser, Iron in Earth surface systems: a major player in chemical and biological processes, Elements 7 (2011) 83-88. DOI: $10.2113 /$ gselements.7.2.83

Received: 3.11.2017

Received in revised form: 11.12.2017

Accepted: 12.12.2017 